\title{
and Health (ICASSETH 2019) \\ The Use of Information and Communication Technology in Learning to Write by Senior High School Students
}

\author{
I Made Sutama* \\ Department of Language and Literature Education \\ Ganesha University of Education \\ Singaraja, Indonesia \\ *imadesutamaubd@gmail.com
}

\author{
I Dewa Gede Budi Utama \\ Department of Language and Literature Education \\ Ganesha University of Education \\ Singaraja, Indonesia \\ idgbudiutama@gmail.com
}

\begin{abstract}
This study aims to describe (1) ICT utilization needs, (2) utilization of ICT, and (3) obstacles faced in utilizing ICT by students in learning to write. To achieve that goal a quantitative descriptive design was used. The subjects of this research were 1242 high school students spread in nine state high schools in Buleleng Regency located inside, outskirts, and out of town. Data were collected by using questionnaire and analysed quantitatively. It was found out that of twelve potential ICT to support students in learning to write, only three are required by most students. There are (1) searching for theory about writing, (2) searching for models of writing in various types of texts, and (3) seeking material for the writing assignment. Of the three potential of ICT required by most students, only two are truly utilized by most students. Both are (1) looking for theory about writing and (2) finding material for the writing assignment. There are three dominant constraints faced by students, both within the city, suburbs, and outside the city, namely: (1) having no ICT tools and (2) internet signals (in schools) are weak, and (3) being unskilled in using ICT. However, there are variations or differences in the proportion of students facing each constraint between regions.
\end{abstract}

Keywords: ICT, learning, write

\section{INTRODUCTION}

Recently, ICT has grown so rapidly. Its developmental speed is marked by the emergence of various ICT products, both in the form of hardware and in the form of software. Those products have been optimally utilized by various people in many fields. We are, for example, certainly no strange to how ICTs are used to support state or government administration. Arrangement of certain permits in a number of agencies has been done online. So also with the delivery of data related to taxes. ICTs have also been exploited in other areas, such as defence and security, economics, and culture.

Then, how about its use in education? The prominent utilization of ICT in all educational institutions related to the administrative system, like academic administration, finance, and human resources. In fact, the affairs of education is not just about administration. Administration is just a helper. Much more important and the core of the world of education is learning.
Learning also requires the use of ICTs. ICT in learning can not only be used in connection with the development and / or provision of instructional media, but also as a means and learning resources for various subjects, including Indonesian Language Lessons, especially in developing writing skills. Since the 1980s, in the world of language teaching, has been known what is called Computer Assisted Language Learning (CALL). The initial model of the CALL program requires students to respond to the stimulus on the computer screen and perform tasks, such as filling in the text of the passengers or performing multiple-choice activities. As ICT access becomes widespread, CALL is no longer just a computer, but has also used the internet and web-based tools.

The use of ICT in learning to write has brought many benefits. Internet resources can enhance and expand the writing process by focusing on different writing forms or genres, using video clips of authors to serve as writing mentors, explaining and facilitating the editing and revising processes, and providing publishing opportunities for student writers [1]. Research by Arslan and Sahin-Kizilproved that the use of blogs has given teachers a tool that is very helpful in writing for middle-level English learners at the University of Turkey [2]. The results of data analysis showed that learning to write which is integrated with the blog resulted in greater improvement in student writing performance. This finding is in line with the findings of Vurdienin Spain [3]. There, it proves that blogs can motivate students to develop their writing skills through self-reflection and peer-to-peer feedback. The point is that ICT with its various aspects has played a significant role in the teaching of both second and foreign languages [4].

While ICT has proven to provide many benefits in writing, among students there is an exhilarating phenomenon. Almost no high school students who do not have any gadgets of its kind, ranging from laptops to mobile phones. Students have grown up with technology, and technology has naturally become a part of life. Access to the Internet is very wide and easier because they can do from their own mobile phones by installing internet cards provided by various companies with affordable prices. 
The problem is for what ICT is needed, how far has it been utilized by students in learning to write, and what are the constraints? This question is more interesting to point out in the middle of the ban on bringing mobile phones to schools in almost all state senior high schools in Buleleng District. Based on the description in the background section previously discussed, the purpose of this study is to know:

- The need for ICT by students in learning to write Indonesian,

- The utilization of ICT which has so far been done by students in learning to write Indonesian,

- Obstacles faced by students in utilizing ICT as a supporter in learning to write Indonesian.

- To achieve the afore mentioned research objectives, the following theories are used as the foundation.

ICT is a set of tools and technology resources used to communicate, create, disseminate, store, and manage information [5]. The world of instruction requires ICT support and, therefore, the development of ICTs needs to be responded well, especially by teachers, including language teachers. Ljungdahl and March stated as educators in the 21st century, we need to accommodate the new information and communication technology in the context of literacy education [6]. ICT can be harnessed to exploit pedagogical potential in the classroom. Cognizant educators living in this digital era cannot simply ignore the myriad modern technology available for exploration, experimentation, and integration into their traditional classroom pedagogies [7]. Therefore, according to Hyland, in a world increasingly dominated by electronic Information and Communication Technology, writing teachers are often confronted with the demand to integrate the technology into the classroom [8].

The new technology has had a huge impact on the way we write, the type of writing we make, the shape of the final product we take, and the way we attract readers. The new technology implies not just what we teach, but it also influences the way we teach [8]. The possibilities of long distance communication with technology have also opened up opportunities for teachers to connect their students with a lot of information, advice, and people, something that was not possible before [8]. The Internet has made it easy for students to get and publish texts online and extend their experience in communicating beyond the classroom, while in-class networks increase interaction between students in conducting opinion feedback and peer response. Thus, there are many benefits to be derived from the use of ICT in learning of writing as delivered by Ljungdahl and March [6].

The Internet is a massive online database that can give its users access to hundreds of millions of multimedia documents [8]. Perhaps the broadest role played by the internet is as a source of research that gives students the data they can use in writing assignments. However, teachers need to be aware that the potential of the internet to obtain information also offers opportunities for students to compile texts from other texts without referring to them and even open the opportunity to download the complete text to fulfil writing assignments which is a form of plagiarism. Another way to exploit the abundance of textual material on the internet is to collect and analyse the language patterns contained in the texts, illustrating texts on various topics as language corporations that can provide insight into the various type of written text. There is a compelling reason to review real data. A database related to authentic writing can help us understand the characteristics of written language and make it clear to students. In addition to being a source of information and compiling corpora, the internet is also a rich source of language learning materials and suggestions related to writing. Finally, the internet provides an alternative space for students to publish their writing. Teachers can design a web page for a class or encourage students to create their own site to load their works.

But be aware that technology, whatever it is, is generally like a two-edged blade: benefits on the one hand, while on the other hand brings harm. Behind the benefits of ICTs for learning, there are also adverse impacts to watch out for [6]. As is known, plagiarism is one of the increasing problems in today's electronic age compared to earlier times [9].

The issue is not only related to the adverse impact of ICT, but also the readiness of teachers to utilize technological progress. Gajek state there are six stages of technological adaptation models by teachers [10]. Phase 1 is conscious: they know of technology but not using it. Phase 2 is learning the process: they try to overcome the frustrations of the first attempt to use technology. Phase 3 is understanding and implementing the process: they identify tasks based on ICTs that are useful in the context of their learning. Stage 4 is familiar and confident: they are confident in using technology. Stage 5 is an adaptation for other contexts: they view the computer as a tool and are more focused on its functionality than on the technology. Stage 6 is a creative application for a new context: they are able to integrate technology into the curriculum and apply it creatively in the classroom. In order to be successful in using technology in the classroom, according to Ljungdahl and March, some things need to be possessed by teachers, such as [6]: positive attitudes toward ICT, adequate knowledge of ICT, and skills in using ICT in learning.

\section{RESEARCH METHODS}

This research was conducted with quantitative design. This design was selected in relation to the research problem and the data needed to answer it.

The subject of this research were the students of state senior high schools in Buleleng Regency. Because of the large number of research subjects, sampling was done. Sampling was done in clusters with school units. Taken $50 \%$ (nine of eighteen) state senior high schools in Buleleng Regency which was considered to be spread in the city, suburb, and outside the city. The nine state senior high schools were (1) SMAN 1 Singaraja, (2) SMAN 3 Singaraja, (3) SMAN 1 Sukasada, (4) SMAN 1 Sawan, (5) SMAN 1 Kubutambahan, (6) SMAN 1 Tejakula, (7) SMAN 1 Banjar, (8) SMAN 1 Busungbiu, and (9) SMAN 1 Gerokgak. Of the nine schools, there were 1242 students involved as samples. Data were collected by 
questionnaire method. Furthermore, the collected data was analysed descriptively quantitatively.

\section{RESULTS AND DISCUSSION}

In accordance with the formulation of the problem, in this section, respectively, will be submitted the results of research with regard to (1) for what ICT is required by students in learning to write Indonesian, (2) for what ICT have been used by the students so far in learning to write Indonesian, (3) what are the constraints faced by students in using ICT as a supporter in Indonesian.

\section{A. Results}

Bellow, submitted for what ICT is needed by students in learning to write Indonesian in State Senior High Schools in Buleleng Regency, for what ICT is used by students in learning to write Indonesian in State Senior High Schools in Buleleng Regency and what are various obstacles faced by students in the utilization of ICT to follow the writing lessons in State Senior High Schools in Buleleng Regency.

Out of twelve potential of ICT to support learning to write, only three are needed by most students (more than $85 \%$ ). They are (1) searching for material (theory) about writing, (2) searching for models/examples of writing in various types of texts, and (3) seeking material for the writing assignment given by the teacher.

Out of the three potentials of ICT required by most students, only two are actually utilized by most students. Both are (1) looking for material (theory) about writing and (2) finding material for the writing assignment given by the teacher.

There were various obstacles faced by students in the utilization of ICT to follow the writing lessons in State Senior High Schools in Buleleng Regency. The data for this problem, were collected from four schools, namely SMAN 1 Singaraja as the representation of in the city schools, SMAN 3 Singaraja as the representation of suburbs schools, and SMAN 1 Gerokgak and SMAN 1 Tejakula as the representation of the outside the city schools.

Based on the data, it can be seen that there are three dominant constraints faced by students, both within the city, suburbs, and outside the city. All three are (1) having no ICT tools or hardware, such as computers, smart phones, modems, etc., (2) the internet signals (in schools) are weak, and (3) being unskilled in using ICTs. However, there are variations or differences in the proportion of students facing each constraint between regions. Getting to the outskirts of the city, for example, the constraint of ownership of facilities is faced by more and more students: in SMAN 1 Singaraja by 8 students, in SMAN 3 Singaraja by 15 students, in SMA 1 Tejakula by 25 students, and in SMAN 1 Gerokgak by 39 students. What is interesting is that all areas have constraints associated with internet signals.

\section{B. Discussion}

There are some interesting findings to be discussed in this section. The first prominent finding was that of twelve potential ICTs to support learning of writing, only three were required by most students (more than $85 \%$ students). They are (1) searching for material (theory) about writing, (2) searching for models of writing in various types of texts, and (3) seeking material for the writing assignment given by the teacher. This condition seems to have something to do with the utilization of ICT by teachers in learning of writing. There are six potential ICTs that are actually utilized by most teachers. Three of the six potential ICTs that teachers actually use are (1) asking students to find material on writing, (2) asking students to find models of writing, and (3) asking students to find material for writing. So, because the teacher asks the students to do all three things, the students then think they are so needed in order to fulfil the teacher's request or task.

The second prominent finding is that of the three potential ICTs expressed to be required by students, only two potentials are actually utilized by most students, namely: finding material about writing and finding material for writing. What is interesting here is the potential to find the model of writing not used by most students. There are several factors that seem to cause it to happen. The first is the model of writing in the textbook is sufficient, especially in textbooks supporting the implementation of Curriculum 2013. Which displayed not only the example of the text, but also the identification of the structure and characteristics of the language. With that, students feel the example is sufficient. Another factor is the experience that it is quite difficult to find an ideal text sample in accordance with the theory taught on the sources that exist on the internet. Based on that experience it seems the students concluded there is no point in tracing the ideal text sample via the internet.

The third prominent finding is that there are three main obstacles faced by students to utilize ICT in learning of writing, namely: (1) lack of ICT tools or hardware, such as computers, smart phones, modems, etc., (2) Weak internet signal, and (3) unskilled in using ICT. The further away from the city, the ownership constraints faced by more and more students. Meanwhile, all regions are experiencing constraints associated with internet signals. The condition of the ownership of the ICT tools appears to be related to student's economic conditions. In general, the children who attend school in the city, especially in excellent schools like SMAN 1 Singaraja, are the children of economically capable families. Thus, it is not difficult for them to have the necessary tools related to ICT. The opposite is owned by children on the outskirts and out of town. They generally come from families with weak economies, so they cannot afford to buy ICT related hardware. If the Internet network is weak in all areas, it appears to be related to not having funds by all schools, especially after various charges have been banned since the management of senior high schools was taken over by the provincial government. The findings of this study are in line with the findings of Mabuan et al. research on students in English class as second language at a private university in the Philippines [7]. It was found that, despite their strong desire to take advantage of email in learning, they face the constraints of computer ownership and internet access both on campus and at home. That's why, they are forced to do work in the cafe (computer shops) that make them incur additional costs 
and spend more time off-campus to do the task. Other researchers in Mabuan et al. also found the same thing [7].

\section{CONCLUSION}

Based on the explanation on the results of the research, it is concluded that not all potential of ICT is optimally utilized by all State Senior High School students in Buleleng Regency in learning to write Indonesian. The most dominant causes are (1) lack of ICT tools or hardware, such as computers, smart phones, modems, etc., (2) Weak internet signals (in schools), and (3) unskilled in using ICTs.

\section{REFERENCES}

[1] S.M. Sweeny, "Writing for the instant messaging and text messaging generation: Using new literacies to support writing instruction," Journal of Adolescent \& Adult Literacy, vol. 54, no. 2, pp 121-130, 2010.

[2] R. Arslan and A. Şand Şahin-Kızıl, "How can the use of blog software facilitate the writing process of English language learners?," Computer Assisted Language Learning, vol. 23, no. 3, pp 183-197, 2010.
[3] R. Vurdien, "Enhancing writing skills through blogging in an advanced English as a Foreign Language class in Spain," Computer Assisted Language Learning, vol. 26, no. 2, pp 126-143, 2013.

[4] M. Foroutan and N. Noordin, "Effect of dialogue journal writing through the use of conventional tools and e-mail on writing anxiety in the ESL context," English Language Teaching, vol. 5, no. 1, pp 10-19, 2012.

[5] E.C. Sharndama and I.A. Jemofwu, "Application of ICTs in teaching and learning English (ELT) in large classes," Journal of Arts and Humanities, vol. 2, no. 6, pp 34-39, 2013.

[6] L. Ljungdahl and P. March, Information and Communication in Wynch, Gordon et al, Literacy: Reading, Writing, and Children's Literature, Oxford: Oxford University Press, 2006.

[7] R.A. Mabuan and G.P. Ebron, "A blended learning approach to teaching writing: using e-mail in the esl classroom," Asian EFL Journal, Issue 100, pp 80-103, 2017.

[8] K. Hyland, Second Language Writing, Cambridge: Cambridge University Press, 2003.

[9] J. Flowerdew and Y. Li, "Plagiarism and second language writing in an electronics age," Annual Review of Applied Linguistics, vol. 27, pp 161-183, 2007.

[10] E. Gajek, "Implications from the use of ICT by language teachersparticipants of international projects," Universal Journal of Educational Research, vol. 3, no. 1, pp 1-7, 2015. 